\title{
ADOLESCENT STUDENTS' CONSUMPTION OF FRUIT, GREENS AND VEGETABLES
}

\author{
Fernanda Dias Batista Monticelli' ${ }^{1}$ José Maria Pacheco de Souza², \\ Sonia Buongermino de Souza ${ }^{3}$
}

\begin{abstract}
Introduction: The intake of fruits, vegetables and greens is in accordance with the recommendations in a minority of the population, especially in adolescents, as it has been shown in literature. The importance to increase this food consumption regards to the prevention of non-transmissible chronic diseases. Objective: was to estimate and describe the frequency of fruit/juice and vegetable intake, and assess the adequacy of this consumption based on the recommendations of the "Ten steps to healthy eating", in adolescents in Curitiba, Brazil. Methods: The food intake frequency was categorized as adequate or inadequate. The relationship between the intake and the independent variables (socioeconomic) was verified by simple and multiple logistic regressions. Results: The participants were 341 adolescents, most female and aged between 10 - 12 years. The most frequent maternal educational level was High School, most of them working outside home. Monthly family incomes up to 3 minimum wages were most frequent. Most adolescents had inadequate intake of fruits/juices and greens/ vegetables, with higher inadequacy for the latter. Only $3.5 \%$ of them had adequate intake of both groups of food. Conclusions: The intake of fruit/juice was not associated with any of the analyzed variables. It was found association of inadequate intake of greens/vegetables only for the age range of 14-19 years, which remained after multiple regression.
\end{abstract}

Key words: adolescent nutrition, food intake, fruits, greens, vegetables, nutrition policy.

\section{INTRODUCTION}

Studies have shown that only the minority of global population consumes the minimum amount of fruits, greens, and vegetables (FGV) recommended by the World Health Organization (WHO), which is $400 \mathrm{~g}$ a day ${ }^{1,2}$. This has been confirmed by recent data from the Brazilian Survey on Family Budgets (Pesquisa de Orçamentos Familiares - POF) in 2008-2009 concluding that over $90 \%$ of the population has a daily intake below the recommended by the Ministry of Health ( $400 \mathrm{~g}$ a day) ${ }^{3}$.

A study done by the National Institute of Cancer (INCA) has verified that in 15 Brazilian capitals, and the Federal District, $66 \%$ of individuals above 15 years old consume FGV five times or more a week ${ }^{4}$. Considering only those from 15 to 24 years old, $45 \%$ consume FGV less than five times a week ${ }^{4}$.
Local researches on the FGV intake among adolescents reinforce the national pattern. In Santa Catarina state, according to a study developed by Farias Jr et al. ${ }^{5}, 46.5 \%$ consumed fruits/greens/ vegetables less than 4 days a week. For adolescents in particular, availability of types of food at home is essential, considering that not being exposed to them is an obstacle to becoming a consumer. However, availability of food at home depends on household's incomes and level of education ${ }^{6-8}$.

Consuming FGV as part of a healthy diet has been mentioned by the WHO's annual report, which suggests that proper intake of fruits, greens and vegetables may help to prevent cardiovascular diseases and certain types of cancer $^{1,2}$.

Raising the intake of fruits, greens and vegetables reduces the energetic density of the diet and leads to a rising on the amount of food that

1 Department of Nutrition, Faculdades Integradas "Espírita".

Department of Epidemiology, Faculty of Public Health - University of São Paulo.

3 Department of Nutrition, School of Public Health - University of São Paulo.

Corresponding Author: fernanda_monticelli@hotmail.com

Suggested citation: Monticelli FDB, Souza JMP, Souza SB. Adolescent students' consumption of fruit, greens and vegetables. Journal of Human Growth and Development 2013; 23(3): 331-337

Manuscript submitted Jan 08 2013, accepted for publication Oct 102013. 
can be consumed to reach a determined level of calories. Fruits, greens and vegetables may replace high-calorie and low-nutritional-value food, as processed cereals and grains and refined sugar, frequently used to prepare industrialized products and fast food, enjoyed by the teenagers ${ }^{9}$.

As a strategy to prevent chronic nontransmissible diseases, WHO and Ministry of Health in Brazil recommend a daily intake of at least 3 portions of greens and vegetables as part of the meals and three portions or more of fruits in desserts and snacks, according to the "Ten Steps for a Healthy Diet", published by the Ministry of Health2,9.

A balanced diet is considered essential for adolescents, with calories and nutrients in enough amounts for following accelerated growth and modifications in body composition common to this stage of life ${ }^{10,11}$.

Accordingly, the proper assessing of adolescent food intake becomes important, mostly for health professionals, as the nutritional habits acquired at this stage may be considered a potential risk factor for obesity and chronic non-transmissible diseases starting in childhood and remaining until adult life ${ }^{12,13}$.

This research aims at estimating and describing the frequency of FGV consumption, as well as assessing its adequacy based on the recommendations offered by the "Ten Steps for a Healthy Diet", published by the Ministry of Health ${ }^{9}$ in adolescent students.

\section{METHODS}

This research was conducted in two public schools maintained by the local government of Curitiba, State of Paraná, Brazil with the second cycle of elementary school ( $5^{\text {th }}$ to $8^{\text {th }}$ grade). The first one was randomly selected downtown and the other one in the suburbs, according to the classification of the Curitiba Department of Education (SME). In 2009, according to SME, 483 students were enrolled in public school 1 , located in downtown (PS1), whereas 505 students were in public school 2, located in the suburbs (PS2).

All the students from $5^{\text {th }}$ to $8^{\text {th }}$ grades were invited to join the research. Therefore, this is a convenience sample. In total, 343 adolescents have participated: 179 students from PS1 (52.2\%) and 164 students from PS2 (47.8\%). Those who were not allowed by parents or the person in charge to participate or who did not return the required documents (surveys and term of consent) were excluded.

Data collection was done by two surveys. Socioeconomic individual variables were collected by a survey with questions on the family demographic and socioeconomic conditions. Survey sheets were delivered to students and forwarded to the persons in charge for filling and returning.
Data on food intake was obtained by means of a survey filled out by students at school, supervised and oriented by a group of researchers, with questions on daily frequency on intake of fruits/ fresh juice, greens and vegetables.

Intake frequency for FGV was considered adequate when equal or superior to 3 times a day, based on the recommendations of the "Ten Steps for a Healthy Diet", from Ministry of Health". It was chosen because of the specific recommendations about the intake frequency of groups of food addressed in this research. Instructions particularly aimed at adolescents, also issued by the Ministry of Health, were refused for not mentioning the adequate intake frequency.

Socioeconomic variables are described by proportions. Mother education is showed in levels and complete years of study. Mother occupation is showed in two categories: yes, when working outside home and no, when does not work, staying at home. The family incomes is showed in minimum wage ranges based on 2009 standards, when this research was conducted (475 Reais).

The intake of fruits/fresh juice, greens and vegetables was described by proportion of daily intake frequency by adolescents. It was then compared to the recommendations and classified in adequate or non-adequate.

The relation among intake, dependent variable (adequate/non-adequate), and independent variables (age, sex, mother education, mother occupation and family incomes) was verified by simple and multiple logistic regression. In simple regression, it was considered $p<0.20$ and in multiple regression $p<0.05$ for association among independent variables and endpoint. From 343 adolescents, two were excluded, due to lack of information on maternal variables; therefore the used sample had 341 individuals. This study was approved by the Committee of Ethics for Research from the Faculty of Public Health, University of São Paulo. All the parents/persons in charge of the students signed the free and clarified consent term.

\section{RESULTS}

From the total number, there were 204 (59.8\%) girls and 137 (40.2\%) boys. Most of them were between 10 and 12 years old, with an average age of 12.6 years $(\mathrm{dp}=1.5)$

Concerning the socioeconomic variables shown in Table 1, most mothers had completed High School. Most of them worked outside home. Most families had incomes of until three minimum wages.

Table 2 shows that most adolescents consumed insufficient amounts of fruits and fresh juices, as well as greens and vegetables, the latter being the lowest. When the intake of both groups of food was assessed, only $3.5 \%$ of adolescents had adequate intake (Table 3 ). 
Table 1: Distribution of adolescents according to demographic and socioeconomic variables. Curitiba, Brazil, 2009

\begin{tabular}{|c|c|c|}
\hline \multirow[t]{2}{*}{ VARIABLE } & \multicolumn{2}{|c|}{ ADOLESCENTS } \\
\hline & $\mathrm{N}$ & $\%$ \\
\hline \multicolumn{3}{|l|}{ Age } \\
\hline $10-11$ & 85 & 24,9 \\
\hline $12-13$ & 159 & 46,6 \\
\hline $14-19$ & 97 & 28,5 \\
\hline \multicolumn{3}{|l|}{ Sex } \\
\hline Female & 204 & 59,8 \\
\hline Male & 137 & 40,2 \\
\hline \multicolumn{3}{|c|}{ Mother education } \\
\hline until $4^{\text {th }}$ grade & 38 & 11,1 \\
\hline 5 th to $8^{\text {th }}$ grade & 92 & 27,0 \\
\hline High School & 148 & 43,4 \\
\hline Higher education & 63 & 18,5 \\
\hline \multicolumn{3}{|c|}{ Mother occupation } \\
\hline Yes & 230 & 67,4 \\
\hline No & 111 & 32,6 \\
\hline \multicolumn{3}{|c|}{ Familiar Incomes (m.w.)* } \\
\hline until 2 & 98 & 28,7 \\
\hline$>2$ a 3 & 98 & 28,7 \\
\hline$>3$ a 5 & 91 & 26,7 \\
\hline$>5$ & 35 & 10,3 \\
\hline No information & 19 & 5,6 \\
\hline
\end{tabular}

Tabela 2: Adequacy of daily intake of fruits/fruits juice and greens/vegetables by adolescents. Curitiba, Brazil, 2009

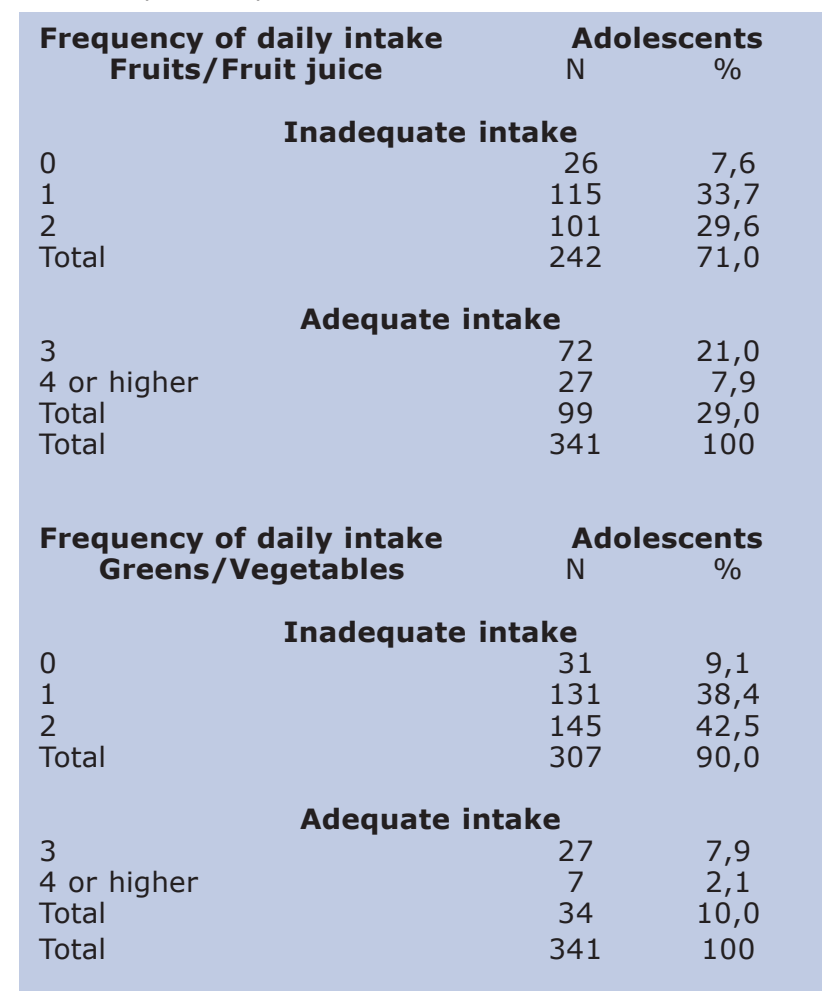

Table 3: Adequacy of daily simultaneous intake of fruits/fruits juice and greens/vegetables by adolescents. Curitiba, Brazil, 2009

\begin{tabular}{|c|c|c|c|c|c|c|}
\hline \multirow[t]{3}{*}{ Fruits } & \multicolumn{4}{|c|}{ Greens/vegetables } & \multicolumn{2}{|c|}{ Total } \\
\hline & & te & & ate & & \\
\hline & $\mathrm{N}$ & $\%$ & $\mathrm{~N}$ & $\%$ & $\mathrm{~N}$ & $\%$ \\
\hline Inadequate & 220 & 64,5 & 22 & 6,5 & 242 & 71,0 \\
\hline Adequate & 87 & 25,5 & 12 & $3,5 *$ & 99 & 29,0 \\
\hline Total & 307 & 90,0 & 34 & 10,0 & 341 & 100 \\
\hline
\end{tabular}

* \% of adequacy of the simultaneous intake of fruits/greens/vegetables: $3,5 \% ; C I: 1,83 \%-6,07 \%$

Tables 4 and 5 present results for simple regressions. The consumption of fruits/juices was not associated to any of the analyzed variables. For greens/vegetables, there was an association between inadequate intake to the higher age range (14 to 19 years old) (OR age 14-19 vs. Age 11-12: $0.29 ; \mathrm{p}: 0.04)$. Other variables were not associated to intake. In order to verify the association between age and greens/vegetables intake across other variables, multiple regression was done; obtained result was the same verified in simple analysis (OR age 14-19 vs. Age 11-12: 0,29;p:0.04).

\section{DISCUSSION}

Studies on the FGV intake frequency by Brazilian adolescents show low frequent intake $14,15,16,17$. This is worrisome, considering that researches have pointed out adequate intake $(400 \mathrm{~g} /$
5 portions a day) is a protecting factor against several chronic diseases. Insufficient intake is among the 10 main risk factors for illness over the world $^{1,2,18}$.

Accordingly, this research found inadequate intake of fruits and juices in adolescents, as well as of vegetables. Considering consumption of the two groups of food, only $3.5 \%$ of the adolescents fit the recommendations.

A population-based transversal study done in 2003 with 812 adolescents between 12 and 19 years old in the city of São Paulo found that only $6.5 \%$ of them reached the recommendation for FGV intake?. Intake of fruits and greens lower to one daily portion was verified in $50.0 \%$ and $38.9 \%$ of adolescents from two schools in São Paulo ${ }^{15}$.

Higher inadequacy of greens and vegetables intake, as this study has verified, has been also observed in students from $8^{\text {th }}$ grade in Rio de Janeiro public city schools. About half of them often 
Table 4: Adequacy of daily intake of fruits/fruits juice according covariables. Simple logistic regressions.Curitiba, Brazil, 2009

\begin{tabular}{|c|c|c|c|c|c|c|c|c|}
\hline \multirow[t]{2}{*}{ Variable } & \multicolumn{2}{|c|}{$\begin{array}{l}\text { Inadequate } \\
<3 x / \text { dia }\end{array}$} & \multicolumn{2}{|c|}{$\begin{array}{l}\text { Adequate } \\
>3 x / \text { dia }\end{array}$} & \multicolumn{2}{|c|}{ Total } & \multirow[t]{2}{*}{ OR } & \multirow[t]{2}{*}{$\mathbf{p}$} \\
\hline & n & $\%$ & n & $\%$ & $\mathbf{n}$ & $\%$ & & \\
\hline $\begin{array}{l}\text { Age } \\
10-11\end{array}$ & \multicolumn{8}{|c|}{ Age } \\
\hline $12-13$ & 114 & 71,7 & 45 & 28,3 & 159 & 100 & 0,85 & 0,57 \\
\hline $14-19$ & 70 & 72,2 & 27 & 27,8 & 97 & 100 & 0,83 & 0,56 \\
\hline \multicolumn{9}{|l|}{ Sex } \\
\hline Female & 145 & 71,1 & 59 & 28,9 & 204 & 100 & 1 & \\
\hline Male & 97 & 70,8 & 40 & 29,2 & 137 & 100 & 1,01 & 0,96 \\
\hline \multicolumn{9}{|l|}{ Mother education } \\
\hline until $4^{\text {th }}$ grade & 27 & 71,0 & 11 & 29,0 & 38 & 100 & 1 & \\
\hline $5^{\text {th }}$ a $8^{\text {th }}$ grade & 62 & 67,4 & 30 & 32,6 & 92 & 100 & 1,23 & 0,63 \\
\hline High school107 & 72,3 & 41 & 27,7 & 148 & 100 & 0,86 & 0,70 & \\
\hline Superior education & 46 & 73,0 & 17 & 27,0 & 63 & 100 & 0,82 & 0,88 \\
\hline \multicolumn{9}{|l|}{ Mother occupation } \\
\hline Yes & 160 & 69,6 & 70 & 30,4 & 230 & 100 & 1 & \\
\hline No & 82 & 73,9 & 29 & 26,1 & 111 & 100 & 0,81 & 0,41 \\
\hline \multicolumn{9}{|c|}{ Family incomes (m.w.)* } \\
\hline until 2 & 67 & 68,4 & 31 & 31,6 & 98 & 100 & 1 & \\
\hline$>2$ a 3 & 68 & 69,4 & 30 & 30,6 & 98 & 100 & 0,95 & 0,88 \\
\hline$>3$ a 5 & 69 & 75,8 & 22 & 24,2 & 91 & 100 & 0,69 & 0,26 \\
\hline$>5$ & 26 & 74,3 & 9 & 25,7 & 35 & 100 & 0,75 & 0,51 \\
\hline No information & 12 & 63,2 & 7 & 36,8 & 19 & 100 & 1,21 & 0,66 \\
\hline
\end{tabular}

* Minimum wage: 475 reais $(\$ 211,9)$

Table ' 5: Adequacy of daily intake of greens/vegetables according covariables. Simple logistic regressions. Curitiba, Brazil, 2009

\begin{tabular}{|c|c|c|c|c|c|c|c|c|}
\hline \multirow[t]{2}{*}{ Variable } & \multicolumn{2}{|c|}{$\begin{array}{c}\text { Inadequate } \\
<3 x / \text { dia }\end{array}$} & \multicolumn{2}{|c|}{$\begin{array}{c}\text { Adequate } \\
>3 x / \text { dia }\end{array}$} & \multicolumn{2}{|c|}{ Total } & \multirow[t]{2}{*}{ OR } & \multirow[t]{2}{*}{$\mathbf{p}$} \\
\hline & $\mathbf{n}$ & $\%$ & $\mathbf{n}$ & $\%$ & $\mathbf{n}$ & $\%$ & & \\
\hline \multicolumn{9}{|l|}{ Age } \\
\hline $10-11$ & 74 & 87,1 & 11 & 12,9 & 85 & 100 & 1 & \\
\hline $12-13$ & 140 & 88,1 & 19 & 11,9 & 159 & 100 & 0,91 & 0,82 \\
\hline $14-19$ & 93 & 95,9 & 4 & 4,1 & 97 & 100 & 0,29 & 0,04 \\
\hline \multicolumn{9}{|l|}{ Sex } \\
\hline Female & 145 & 71,1 & 59 & 28,9 & 204 & 100 & 1 & \\
\hline Male & 97 & 70,8 & 40 & 29,2 & 137 & 100 & 1,20 & 0,62 \\
\hline \multicolumn{9}{|l|}{ Mother Education } \\
\hline until $4^{\text {th }}$ grade & 27 & 71,0 & 11 & 29,0 & 38 & 100 & 1 & \\
\hline $5^{\text {th }}$ a $8^{\text {th }}$ grade & 62 & 67,4 & 30 & 32,6 & 92 & 100 & $1,1 \overline{1}$ & 0,88 \\
\hline High school107 & 72,3 & 41 & 27,7 & 148 & 100 & 1,51 & 0,53 & \\
\hline Superior education & 46 & 73,0 & 17 & 27,0 & 63 & 100 & 1,23 & 0,78 \\
\hline \multicolumn{9}{|l|}{ Mother occupation } \\
\hline Yes & 160 & 69,6 & 70 & 30,4 & 230 & 100 & 1 & \\
\hline No & 82 & 73,9 & 29 & 26,1 & 111 & 100 & 0,99 & 0,98 \\
\hline \multicolumn{9}{|c|}{ Familiar Incomes (m.w)* } \\
\hline until 2 & 67 & 68,4 & 31 & 31,6 & 98 & 100 & 1 & \\
\hline$>2$ a 3 & 68 & 69,4 & 30 & 30,6 & 98 & 100 & 1,31 & 0,60 \\
\hline$>3$ a 5 & 69 & 75,8 & 22 & 24,2 & 91 & 100 & 2,36 & 0,08 \\
\hline$>5$ & 26 & 74,3 & 9 & 25,7 & 35 & 100 & 1,22 & 0,78 \\
\hline No information & 12 & 63,2 & 7 & 36,8 & 19 & 100 & 0,72 & 0,77 \\
\hline
\end{tabular}

*Minimum wage: 475 reais $(\$ 211,9)$

ingested fruits, but raw salad and cooked vegetables were consumed as frequently by only $20 \%$ and $16.5 \%$ of them, respectively ${ }^{19}$.

Ximenes et al. ${ }^{20}$ have pointed out that thi group of food has the lowest intake level amon adolescents in an average age of 14 years old from public and privates schools in Recife, State of Pernambuco, Brazil.

In this study, results of simple regressions show that none of the analyzed variables was 
associated to the intake of fruits and juices; in regard to greens and vegetables only age was associated to intake. Possibly the found association is related to the weaker influence parents have on their children in later ages, when peers and media become more important over adolescents' habits. Similar findings were reached by Mendes ${ }^{21}$ (2009), in a city of the State of Minas Gerais, Brazil, and Larson et al.22 (2007), in Minnesota, USA.

A cohort study with Norwegian teenagers showed prevalence of daily fruit intake reduced about $30 \%$ between 14 and 20 years old. Vegetable consumption reduced to about half within the same period, with a rise on sugar ingestion from soft drinks ${ }^{23}$

A study focusing on African-American teenagers found older individuals tend to consume less fruits, and vegetables as they are more capable of taking their own decisions ${ }^{24}$.

However, Farias Jr and Lopes ${ }^{14}$ did not reach the same conclusion in a study with adolescents living in Florianópolis, State of Santa Catarina, Brazil. FGV intake was not related to age.

As previously mentioned, this study found no association among intake level and sex or socioeconomic variables.

There are different opinions regarding adequacy of fruit and vegetable intake according to sex. Some researches show girls' intake are closer to the recommendations over boys ${ }^{5,14,25}$. It may be related to stronger concerns over body image and diets among girls. In the other hand, Toral et al. ${ }^{15}$ observed higher consumption of fruits among boys.

Family incomes may be considered as determinant on FGV intake of adolescents, but in a controversial way. Neutzling et al. ${ }^{26}$ suggest adolescents belonging to wealthier families seem to have some protection against low intake of FGV. It could be explained by difficulties on buying FGV in families with lower purchasing power ${ }^{7}$. Nevertheless, adolescents with higher family incomes consumed less fruits/vegetables, according to Farias Jr et al. ${ }^{5}$. The same was observed for the consumption of fruits according to the research conducted by Mendes and Catão ${ }^{25}$. The opposite was found for greens/vegetables: the higher the incomes, the higher the intake level.

\section{REFERENCES}

1. World Health Organization (WHO). The world health report 2002: reducing risks, promoting healthy live. Geneva: World Health Organization, 2002. p. 60-1;118;176.

2. World Health Organization (WHO). World Health Organization. Diet, nutrition and the prevention of chronic diseases. Report of a Joint WHO/FAO Expert Consultation. Geneva: WHO; 2003. WHO Technical Report Series, 916. p.23-5; 56.
Claro et al. ${ }^{27}$, in analysis of the Survey on Family Budgets (POF) from the University of São Paulo Institute of Economic Research (FIPE-USP), conducted in 1998-1999, verified that in the city of São Paulo higher incomes were associated to higher expenditure on fruits and vegetables, whilst the same did not apply for greens ${ }^{27}$. The findings show the amount spent on FGV corresponded to nearly $2 \%$ of the households' month incomes and little more than $10 \%$ of the total amount spent on food, being higher for fruits $(5.1 \%)$, than greens $(3.8 \%)$ and vegetables $(1.3 \%)^{27}$

In regards to Brazil, data from national POF from the Brazilian Institute of Geography and Statistics (IBGE), in 2002-2003, found even families pursuing higher incomes did not consumed the minimum recommended amount of FGV $(400 \mathrm{~g})^{27,28}$. This was confirmed by the most recent POF-IBGE conducted in 2008-2009, which showed daily FGV intake is below the recommended levels for over $90 \%$ of the Brazilian population ${ }^{3}$.

Parents education is pointed out by some authors as determining for FGV intake. More years of study would be related to higher intake, according to Bigio et al. ${ }^{7}$.

Regarding mother occupation, Casotti and collaborators ${ }^{29}$, concluded that mothers who do not work outside home or work as home employees are more used to preparing meals and opting for fresh food and those who had another kind of occupation, less related to home, thus preferring industrialized products. Moreover, absence of mother during meals is pointed out as a related factor for lower intake of vegetables and fruits by adolescents ${ }^{30}$.

Besides insufficient intake of FGV, adolescents tend to favor types on food related to unhealthy habits, such as candies/sweets, soft drink, and fast food, e.g. hamburger, hot dog or potato chips ${ }^{19,30}$. Such behavior is strongly influenced by the media, which directs its advertisements to younger audiences for considering them open to new ideas $^{31,32}$. It was found that food belonging to the group of sugar/sweets and fat are more favored by advertisements than those showing fruits and vegetables ${ }^{33,34}$.

This study concludes that adolescents consume FGV in inadequate levels and, particularly regarding greens and vegetables, it tends to reduce in later ages.

3. Instituto Brasileiro de Geografia e Estatística (Brasil) em parceria com Ministério da Saúde [internet]. Pesquisa de Orçamentos Familiares (POF), 2008-2009. Mais de 90\% da população comem poucas frutas, legumes e verduras. Rio de Janeiro: 2010. Disponível em: http:// www.ibge.gov.br/home/presidencia/noticias/ noticia_visualiza.php?id_noticia $=1937 \& i d \_p a g i n a=1$

4. Instituto Nacional de Câncer (INCA); Secretaria de Vigilância em Saúde (Brasil). Inquérito domiciliar sobre comportamentos de risco e 
morbidade referida de doenças e agravos No transmissíveis. Rio de Janeiro; 2005. p. 14-9.

5. Farias JC Jr, Nahas MV, Barros MVG, Loch MR, Oliveira ESA, De Bem MFL, et al. Comportamentos de risco à saúde em Adolescentes no Sul do Brasil: prevalência e fatores associados. Rev Panam Salud Publica/Pan Am J Public Health. 2009; 25(4): 334-52.

6. Estima CCP, Philippi ST, Santos MA. Fatores determinantes de consumo de alimentos: porque os indivíduos comem o que comem? Rev Bras Nutr Clínica. 2009; 24(4): 263-8.

7. Bigio RS, Verly Junior E, Castro MA, César CLG, Fisberg RM, Marchioni DML. Determinantes do consumo de frutas e hortaliças em adolescentes por regressão quantílica. Rev Saúde Pública. Jun 2011; 45(3): 448-56.

8. Santos JS, Costa MCO, Nascimento Sobrinho CL, Silva MCM, Souza KEP, Melo BO. Perfil antropométrico e consumo alimentar de adolescentes de Teixeira de Freitas.Bahia. Rev Nutr. 2005; 18(5): 623-32.

9. Ministério da Saúde (Brasil). Secretaria de Atenção à Saúde. Guia alimentar para a população brasileira: promovendo a alimentação saudável / Ministério da Saúde, Secretaria de Atenção à Saúde - Brasília : Ministério da Saúde, 2008. (Série A. Normas e Manuais Técnicos). p. $51-8 ; 197-202$.

10. Damiani D, Carvalho DP, Oliveira RG. Obesidade na Infância: Um grande Desafio. Pediatr mod. 2000; 36(8): 489-528.

11. Almeida C da F, Pereira RBC, Bittencourt A, Ribeiro RL, Coelho SC. Frequência de consumo alimentar versus saúde de adolescentes. Rev Rede de Cuidados em Saúde. 2009; 3 (3): 1-12.

12. Slater B, Enes CC, López RVM, Damasceno NRT, Voci SM. Validation of a food frequency questionnaire to asses the consumption of carotenoids, fruits and vegetables among adolescents: The Method of Triads. Cad Saúde Pública. 2010; 26 (11): 2090-100.

13. Miranda AAN de, Navarro F. A prevenção e o tratamento da obesidade durante a infância: uma opção eficaz para reduzir a prevalência desta patologia. Revista Brasileira de Obesidade, Nutrição e Emagrecimento, São Paulo Jul/ Ago. 2008; 2 (10): 313-23.

14. Farias JC Jr, Lopes AS. Comportamentos de risco relacionados à saúde em adolescentes. $R$ Bras Ci e Mov. 2004; 12 (1): 7-12.

15. Toral N, Slater B, Cintra I de P, Fisberg M. Comportamento alimentar de adolescentes em relação ao consumo de frutas e verduras. Rev Nutr Campinas, maio/jun., 2006; 19 (3): 331-40.

16. Leal GV da S, Philippi ST, Matsudo SMM, Toassa EC. Consumo alimentar e padrão de refeições de adolescentes, São Paulo, Brasil. Rev Bras epidemiol 2010; 13 (3): 457-67.

17. Gonçalves, NA, Cecchi PP, Oliveira MM, Mollo VMH, Blaya AF, Philippi ST, Szarfarc SC. Consumo Alimentar de Adolescentes praticantes de canoagem. Journal of Human Growth and Development. 2012; 22 (1): 1-7.

18. World Health Organization (WHO). Dietary intake of fruit and vegetables and risk of diabetes mellitus and cardiovascular diseases. 2004 [updated 2005; cited 2008 Jul 17]. Disponível em: http://www.who.int/ dietphysicalactivity/publications/ f\&v_cvd_diabetes.pdf. p 28-34.

19. Castro IRR, Cardoso LO, Engstrom EM, Levy RB, Monteiro CA. Vigilância de fatores de risco para doenças não transmissíveis entre adolescentes: a experiência da cAge do Rio de Janeiro, Brasil. Cad Saúde Pública, Rio de Janeiro. Oct. 2008; 24 (10): 2279-88.

20. Ximenes R, Leimig L, Couto GBL, Colares V. Hábitos alimentares em uma população de adolescentes. Odontologia. Clín-Científ. Recife. Out/Dez., 2006. 5 (4): 287-92.

21. Mendes KL. Alimentação na adolescência: um estudo sobre o consumo de frutas, legumes e verduras e verduras na atualidade. Dissertação (Mestrado) . Universidade do Estado de Minas Gerais, Fundação Educacional de Divinópolis. 2009. Pgs 1-117.

22. Larson NI, Neumark-Sztainer D, Hannan PJ, Story M. Trends in adolescent fruit and vegetable consumption, 1999-2004. Am J Prev Med. Feb 2007; 32 (2): 147-50.

23. Lien N, Lytle LA, Klepp KI. Stability in consumption of fruit, vegetable, and sugary foods in a cohort from age 14 to age 21. Prev Med. Sep 2001; 33 (3): 217-26.

24. Di Noia J, Contento IR. Fruit and vegetable availability enables adolescent consumption that exceeds national average. Nutr Res. Jun 2010; 30 (6): 396-402.

25. Mendes KL, Catão LP. Avaliação do consumo de frutas, legumes e verduras por adolescentes de Formiga - MG e sua relação com fatores socioeconômicos. Alim Nutr Araraquara. Abr/ Jun 2010; 21 (2): 291-96.

26. Neutzling MB, Araújo CLP, Vieira M de FA, Hallal $P C$, Menezes AMB. Frequência de consumo de dietas ricas em gordura e pobres em fibra entre adolescentes. Rev Saúde Pública, São Paulo. Jun 2007; 41 (3): 336-42.

27. Claro RM, Do Carmo HCE, Machado FMS, Monteiro CA. Renda, preço dos alimentos e participação de frutas e hortaliças na dieta. Rev Saúde Pública. São Paulo. Ago 2007; 41 (4): 557-64.

28. Instituto Brasileiro de Geografia e Estatística (Brasil). Pesquisa de Orçamentos Familiares (POF), 2002-2003. Aquisição alimentar domiciliar per capita, Brasil e grandes regiões. Rio de Janeiro, 2004. Disponível em: http:// 
www.ibge.gov.br/home/estatistica/populacao/ condicaodevida/pof/2002aquisicao/ aquisicao.pdf.

29. Casotti L, Ribeiro A, Santos C, Ribeiro P. Consumo de Alimentos e Nutrição: dificuldades práticas e teóricas. Cadernos de Debate, Vol. VI, 1998. Núcleo de Estudos e Pesquisas em Alimentação da UNICAMP, páginas 26-39.

30. Cardoso L de O, Alves LC, Castro IRR de, Leite I da C, Machado CJ. Uso do método Grade of Membership na identificação de perfis de consumo e comportamento alimentar de adolescentes do Rio de Janeiro, Brasil. Cad Saúde Pública. Fev 2011; 27(2): 335-46.

31. Nunes MM de A, Figueroa JN, Alves JGB. Excesso de peso, atividade física e hábitos alimentares entre adolescentes de diferentes classes econômicas em Campina Grande (PB). Rev
Assoc Med Bras. São Paulo. Apr 2007; 53 (2): 130-34.

32. Motta-Gallo S, Gallo P, Cuenca A. The influence of television on the eating babits of Brazilian children. Journal of Human Growth and Development. 2013; 23 (1): 87-93.

33. Carvalho EB de. Influência das Propagandas de Televisão na Alimentação de Crianças e adolescentes, 2009. Bacharel em Nutrição pela PUC-Campinas. Pg 23 a 30. In: BOCCALETTO EMA; MENDES RT (Organizadores). Alimentação, Atividade Física e Qualidade de Vida dos Escolares do Município de Vinhedo/SP. Campinas: IPES Editorial, 2009.

34. Almeida S, Nascimento PC, Quaioti TC. Quantidade e qualidade de produtos alimentícios anunciados na televisão brasileira. Rev Saúde Pública. São Paulo. Jun 2002; 36 (3): 353-55. 